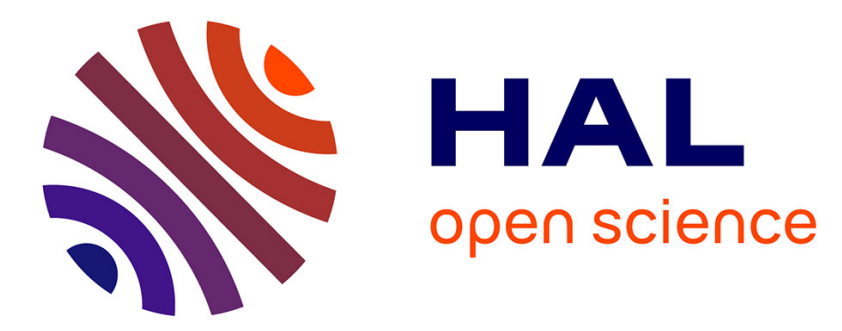

\title{
Selected It Tools in Enterprise Knowledge Management Processes - Overview and Efficiency Study
}

Maciej Pondel, Jolanta Pondel

\section{To cite this version:}

Maciej Pondel, Jolanta Pondel. Selected It Tools in Enterprise Knowledge Management Processes - Overview and Efficiency Study. 5th IFIP International Workshop on Artificial Intelligence for Knowledge Management (AI4KM), Aug 2017, Melbourne, VIC, Australia. pp.12-28, 10.1007/978-3030-29904-0_2. hal-02517701

\section{HAL Id: hal-02517701 \\ https://hal.inria.fr/hal-02517701}

Submitted on 24 Mar 2020

HAL is a multi-disciplinary open access archive for the deposit and dissemination of scientific research documents, whether they are published or not. The documents may come from teaching and research institutions in France or abroad, or from public or private research centers.
L'archive ouverte pluridisciplinaire HAL, est destinée au dépôt et à la diffusion de documents scientifiques de niveau recherche, publiés ou non, émanant des établissements d'enseignement et de recherche français ou étrangers, des laboratoires publics ou privés. 


\title{
Selected It Tools in Enterprise Knowledge Management Processes - Overview and Efficiency Study
}

\author{
Maciej Pondel ${ }^{1}$ and Jolanta Pondel ${ }^{2}$ \\ ${ }^{1}$ Wrocław University of Economics, \\ Komandorska 118/120, Wrocław, Poland \\ Email: maciej.pondel@ue.wroc.pl \\ ORCID : 0000-0002-1978-6571 \\ ${ }^{2}$ WSB University in Wrocław, \\ Fabryczna St. 29-31, 53-609 Wrocław, Poland \\ Email: jolanta.pondel@wsb.wroclaw.pl \\ ORCID: 0000-0002-9562-7783
}

\begin{abstract}
Today enterprises work in a rapidly changing environment. Those changes bring uncertainty about future that can result in high risks but also in new business opportunities. Modern communication technologies enable a better management of information and knowledge flows, what is essential to achieve a success in business. Digitalization processes experienced by modern companies require improvement of communication processes and knowledge management. This paper elaborates the essence of communication in modern companies. It overviews available IT tools supporting communication and knowledge management in enterprise. The aim of this article is to assess the current level of use of IT tools supporting knowledge management, by the companies considered as leaders in Poland, so the last part of the paper presents results of a survey research concerning usage, expectations and evaluation of available tools in Polish companies.
\end{abstract}

Keywords: Communication $\bullet$ IT communication tools $\bullet$ enterprise social $\bullet$ selfservice business intelligence $\bullet$ knowledge management.

\section{Introduction}

It is vital for every business to attract top-quality employees because the potential of human resources determines the potential of the whole enterprise. Currently, employees are digitally and globally oriented, they expect diversity, and they are eager to participate in social media. At the same time, market expectations, customer's and client's needs and business requirements evolve faster than ever before. Enterprises may perceive change in terms of business challenges or opportunities. Those changes force an execution of necessary personnel changes. In this aspect companies can or- 
ganize, create, implement platforms, processes and tools that will streamline processes. Technological development and communication solutions often allow better communication and more efficient corporate knowledge management. Initially, modern technological solutions caused much controversy. Organizations primarily were afraid of uncontrolled spread of information and low security of information. Enterprises were accustomed to full control of communication processes but they noted that in the age of mobility, BYOD and social networks they can lose efficiency and employee engagement, which has led them to take advantage of modern communication platforms.

Communication is most commonly performed by the Internet and the services Internet offers. According to literature, 615 million Europeans regularly use Internet. Taking into account 2000-2016, the growth of Internet users in Europe is 485,2\%. The number of people using the Internet worldwide is already 3,675 billion. However, despite the fact that these values are very high and seems promising (given the popularity of using Internet communication technologies), there are still areas in the world that are cut off from the Internet and some of its services, such as the Web 2.0 or mobile services. According to sources only about $50,1 \%$ of the global population actively use the Internet [1].

First section of this paper elaborates the essence of communication and knowledge management in enterprises. Next section covers the types of communication in companies. Third chapter elaborates the requirements regarding communication system in companies and presents typology of communication tools. Following section overviews available IT tools supporting communication and knowledge management. Last chapter introduces the result of a survey research regarding usage, expectations and evaluation of available tools in Polish companies.

\section{The essence of communication and knowledge management in enterprises}

The competitiveness of an enterprise depends on the skills and involvement of employees, which is related to the access of information and knowledge and exchange of information between management, employees, customers, etc. Effective communication and the flow of information and knowledge enable the proper functioning of people and teams and it motivates to work.

Word communication "communication" (lat.) - connection, other meanings in different languages are message, commonality [2]. In other words communication means exchanging information between two or more people (employees).

In literature, the process of effective communication means "sending a message in such a way that the message received is as close as possible to the intended message" [3], "a process in which people strive to share meaning through symbolic messages (messages) "[4]. The purpose of communication is shaping, modification, change of knowledge, attitudes, behaviors, indications, suggestions of ways of acting. Efficient communication is crucial to achieve proper knowledge management in organization. 
The objective of Knowledge Management System is to support creation, transfer, and application of knowledge in organizations [5].

Communication and knowledge management in an enterprise are recognized as a fundamental factor of proper company functioning, because it is closely linked to the management of the enterprise. Effective communication is essential for executives to set up tasks, plans, communicate information to employees, etc., while employees provide their own views on the activities, plans, accomplishing the tasks, communicating with the clients. Communication allows each other to interact with others, and depending on the skills may be stronger or weaker, faster or slower. It is worth mentioning that business communication is usually directly linked to the core management functions, i.e. planning, organizing, motivating and controlling, and executing those functions through the communication process.

Mintzberg pointed out 3 types of managerial roles related to communication [4]:

1. interpersonal - connector, representative, leader communicating with subordinates, customers, suppliers and colleagues in the organization,

2. information - monitor, spokesman disseminating information on tasks, work, duties, provide information about the enterprise, department as a whole,

3. decision-making - negotiator, entrepreneur, implementing new projects, resolving conflicts, allocating resources, tasks.

\section{Types of communication in enterprises}

An effective communication process plays an important role in the company's performance and effectiveness. Employees performing tasks in collaboration create specific relationships, influence others' behavior, convey information and knowledge, and enforce certain values, norms, and patterns of behavior. Effective communication enables the development of employees through the exchange of knowledge and experience. It helps them to better understand the assigned tasks and expectations regarding the way of implementation and execution.

Communication in the enterprise can be divided in regards to [6-7]:

- Flow direction:

1. vertical - exchange of information between employees and supervisors (between different levels of management);

2. horizontal - exchange of information between members of the same team or persons performing the same function.

- Nature of information transmission:

1. formal - resulting from the organizational structure of the company,

2. informal - formed on the basis of informal relationships between employees.

- Message type:

1. private - sent to friends for informal purposes (not related to official duties); 
2. business (but not public) - their purpose is to inform the recipient about work related matters,

3. public - sent to many people directly and simultaneously.

- Nature of the interaction:

1. direct - exchange of information directly, usually intended to trigger specific activities,

2. indirect - the transmission of information not directly when additional individuals, means of communication, technical devices are involved.

- Scope of impact:

1. between the company and the environment - exchange of information, between employees and outsiders,

2. inside the company - exchange of information between members of the enterprise,

3. interpersonal communication - exchange of information between its participants.

- Information flow in communication networks:

1. centralized communication - facilitates solving simple problems, usually indicated by procedures (not too effective for solving complex problems);

2. decentralized communication - takes into account the real needs and capabilities of employees, facilitates solving more complex tasks.

The basis for communication is to reach and manage useful information, so the form, the way, the timing of the transfer of relevant information, and the use of decision-making information are of great importance. Depending on what to whom, when you want to be communicated, you need to select the right communication channel, and the use of a specific form of communication affects how the recipient reacts to the message.

\section{$4 \quad$ Enterprise communication system}

Enterprise successes on the market when it fulfills its mission, the quality of the products and services it offers is satisfactory, the company has a reputation for being credible, it has a well-established market position, and makes the desired profit. Success depends on many factors. One of them is the right communication and knowledge management both inside and outside the enterprise.

Well-planned communication system in the enterprise creates the opportunity of [8-9]:

- increase work efficiency,

- problems identification,

- finding ways to solve problems,

- increase employee involvement and loyalty, 
- raising overall motivation for work and organizational culture,

- improving people-to-people relationships and understanding,

- understanding the needs of change and reduce resistance to change,

- creating values relevant for the proper development of the company.

Introduced, modified communication system in the company should:

- take into account information and knowledge needs of employees,

- establish key communication areas (of particular importance to the company, resulting in expected employee attitudes, identify the purpose and forms of communication);

- distinguish employees / teams according to the scope of information needs and adapt them to forms of communication,

- establish rules for checking the effectiveness of processes, communication tools and their impact on the functioning of an enterprise.

Businesses collect more and more data and information for problem solving and decision-making processes, both in operational and strategic areas. This would not be possible without the use of information technology, information and knowledge management, and the use of specific IT tools to streamline the process. The effectiveness of the tasks performed and the decisions made is influenced by, among others, the ability to appropriately select IT tools for communication, sources of information, speed of acquisition, processing of information and knowledge. Properly chosen tools for communication and knowledge management help you make the most accurate decision in the shortest possible time, with low risk.

Contemporary enterprise electronic communication tools include:

- Intranet (extranet),

- Email,

- Instant Messaging / chat,

- Audioconference / teleconference,

- Videoconference with desktop sharing,

- Corporate blog,

- Social networking (enterprise social),

- Enterprise wiki,

- Individual and group calendar,

- Document management system,

- Task management systems,

- Business intelligence system for creating and sharing management dashboards.

\section{Examples of communication and knowledge management tools in enterprise}

Efficient communication platform in modern enterprise should enable employees: 
- Collaboration,

- Content / Information publishing

- Social networking

- Real time communication

- Task and goals assignment and they further discussions/ clarification,

- Document management,

- Information search,

- Workflow management,

- Reporting, analyses and insights sharing.

Collaboration software is designed to improve productivity of individuals, teams and organizations. This is achieved through the following capabilities of collaboration software (see [10]):

- informing,

- coordinating,

- actually collaborating,

- cooperating.

Examples of collaboration software are:

- In terms of content and information management:

- Liferay,

- Atlassian Confluence,

- Microsoft SharePoint being presented in Fig. 1.

- In terms of social networking

- Yammer being presented in Fig. 2,

- Slack,

- IBM's Connections.

- In terms of real time communication

- Atlassian HipChat,

- Skype For Business,

- Jabber. 

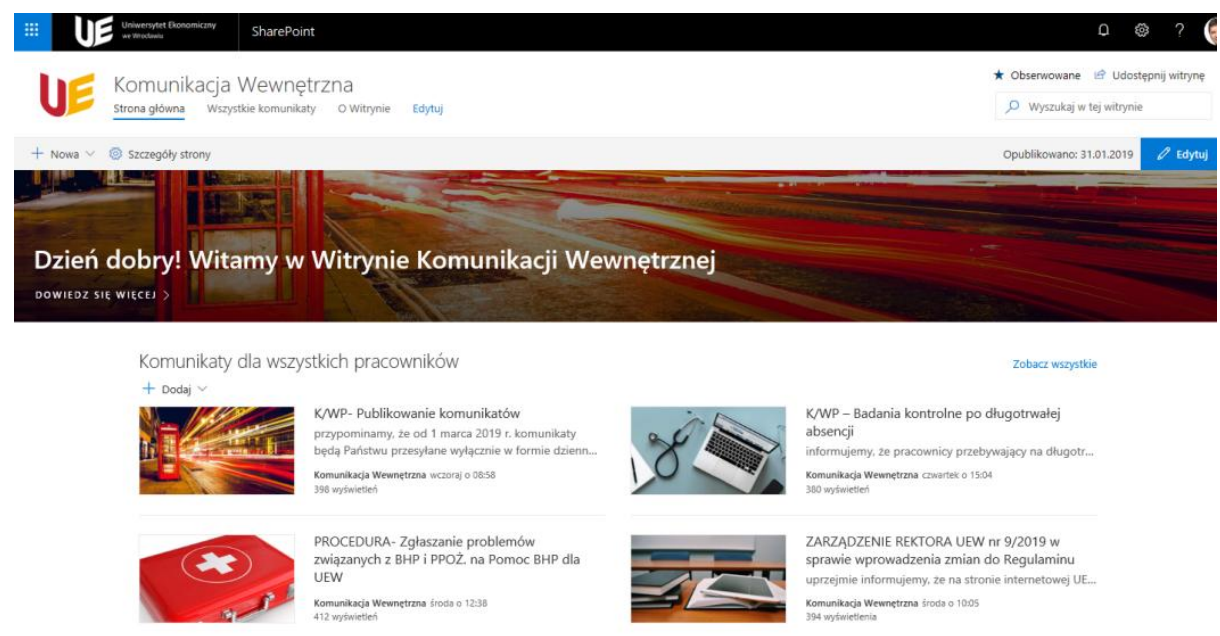

Komunikaty dla pracowników naukowo - dydaktycznych + Dodaj

K/NA - Informacja w sprawie stosowania $50 \%$
kosztow uzzskania przychodu przez nauczycief

Fig. 1. Example of MS SharePoint site

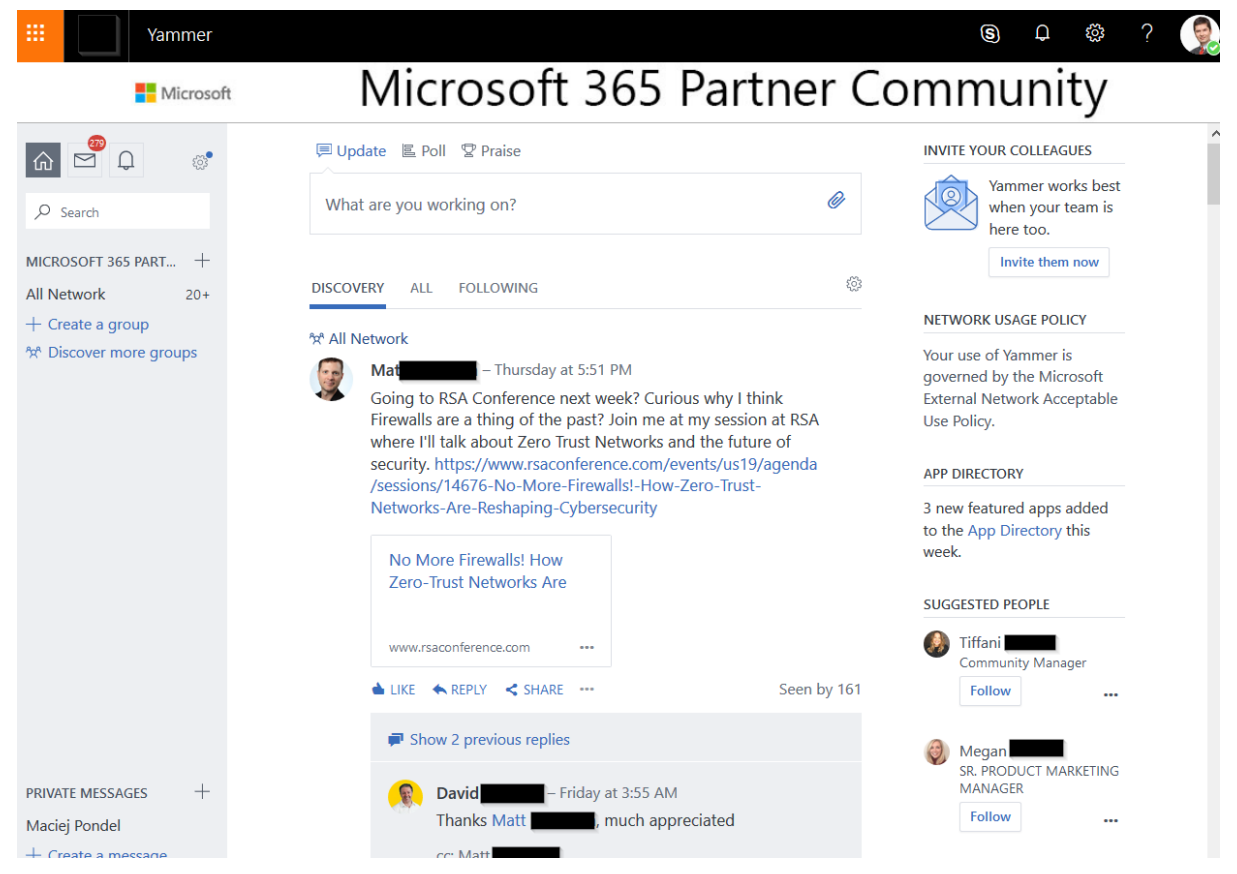

Fig. 2. Example of Yammer home page. 
Tasks and goals assignment to employees and execution progress tracking can be supported by an issue tracking system (ITS). It is a software application that allows enterprise to record and follow the progress of every task or a problem or "issue" that a team member identifies, until the problem is resolved. With an ITS, an "issue", which can be anything from a simple customer question to a detailed technical report of an error or bug or even a goal to achieved by employee (useful in Management by Objectives approach). Issue can be tracked by priority status, owner or some other customized criteria.

An ITS provides the user with a way to report an issue, track progression towards its resolution, and know who is responsible for task competition. It also allows the manager of the system to customize the tracking procedure so that unnecessary documentation on the part of the problem solvers does not become a waste of time. Many kinds of enterprises use ITS applications, including software developers, manufacturers, IT help desks, and other service providers [11].

Examples of such applications are:

- Atlassian Jira,

- Trello,

- Redmine,

- Microsoft Office 365 Planner - presented in Figure 3.

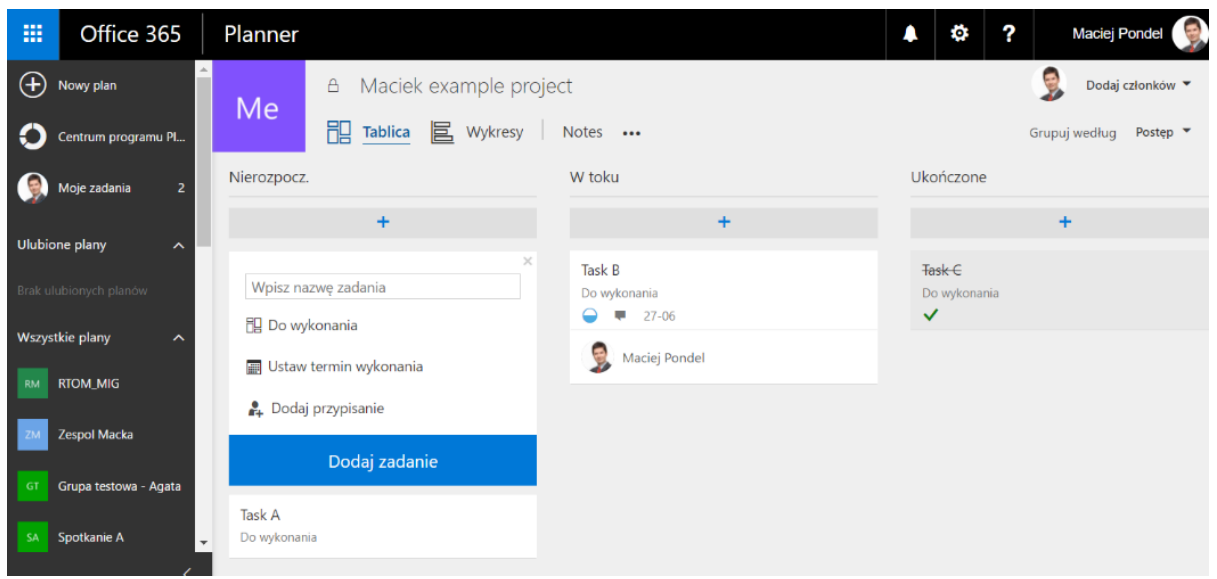

Fig. 3. Example of Microsoft Office Planner application

Workflow systems are considered mainly as tools supporting business processes. A workflow application implements a business process model. The model describes the process steps to be performed to achieve a specific business goal, business rules for coordination of those steps and responsibilities of process participants [12]. The steps include tasks that should be performed by agents that can be human, computer systems or combination of both [13]. Workflow systems, with the benefits of efficient and flexible process modelling and process automation, have been widely used for managing business processes. Communication and knowledge management processes 
are very often treated as a small processes that should be executed according to the business rules defined in a workflow tool eg:

- Document approvals - business rules define who is responsible for creation and approval of documents. Every kind of document can have individual list of approvers.

- Change management - the workflow can define how the change should be identified, described, estimated and who should be responsible for its approval and execution.

- Risk management - the workflow can enforce the specified risk description by a project manager and can lead the process of execution of preventive actions.

- And many more.

There are many software applications enabling workflow automation. Usually they provide user with Graphical User Interface where users can model the process and then the flows are executed. An example process automation application MS Flow is presented in Fig. 4 . One can observe there a modelling feature of the application that allows building process by selecting "boxes" representing actions and connecting them in order to reflect business rules. The main advantages of such applications are:

- Increasing productivity of employees,

- Ability to measure to productivity,

- Precise execution of business functions (in accordance with the assumed process).

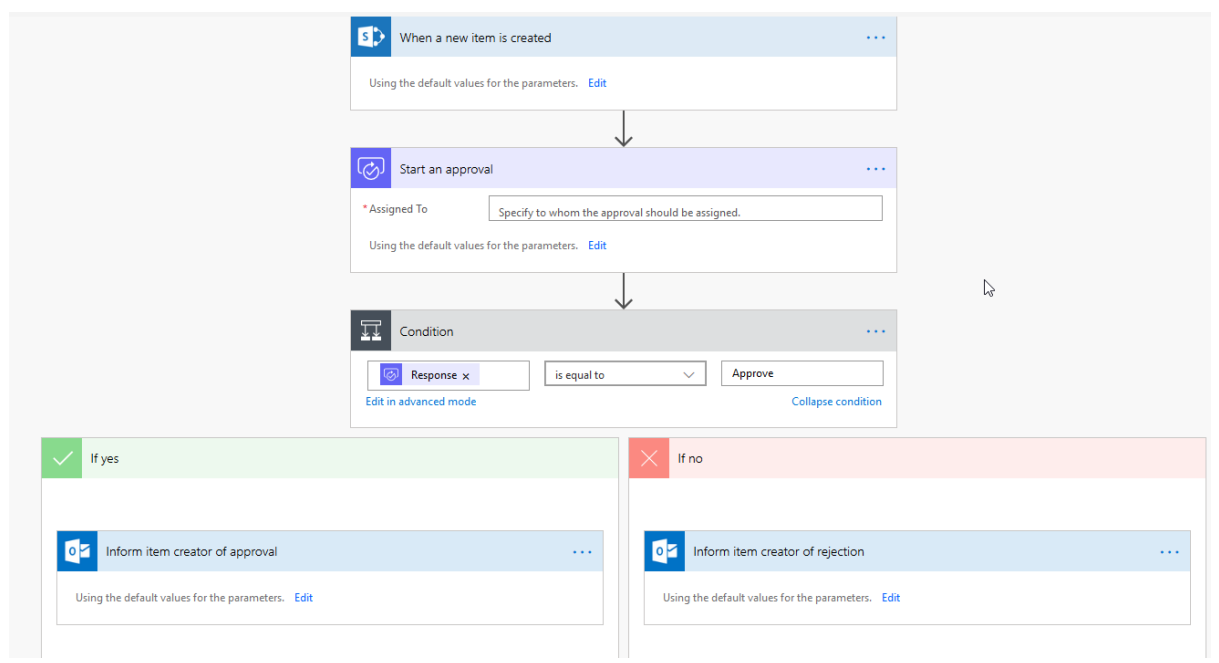

Fig. 4. Example of Microsoft Flow application 
Reporting and analyses are essential when we would like to control and monitor all aspects of the company. We use Business Intelligence tools that could integrate the data from all the systems used in a company to present the holistic reports. Regarding Business Intelligence tools we can distinguish.

- Traditional BI based on ETL process, data warehouses, data marts, OLAP, dashboards, scorecards and analytics.

- Self Sevice BI where Power Users connect to various data sources and create their data models on which they build visualisation layer.

Examples of most common Self Service Business Intelligence tools are:

- Microsoft Power BI,

- Tableau,

- QlikView.

Power BI is a Microsoft developed suite that belong to the group of tools called Self Service BI. Of course the main goal of such tool is to provide Business Intelligence capability but the difference expressed in Self-service boils down to the fact that in this tool the final user (accountant, analyst, manager and many other) is capable to build their own analysis (data models, reports, dashboards) with only limited assistance of the IT department (see [14]).

Also, it's important to emphasize that there are two kinds of self-serve BI user (see [15]):

- Analytics Power Users who create visual apps from multiple data sources - both internal and external.

- Regular Users that can fully explore the visual apps created by power users or IT.

Power BI is a cloud-based business analytics service that provides user with the most important BI features like creating rich interactive reports with Power BI Desktop and monitoring the health of business using live dashboards. It includes 2 main approaches to analyse data:

- Power BI Desktop,

- Power BI for Office 365.

Power BI desktop is a free desktop tool in which you can (see [16]):

- Import.

You can import data from a wide variety of data sources. After user connects to a data source, he or she can shape the data before importing to match analysis and reporting needs.

- Model data. 
Power BI Desktop provides data modelling features like autodetect and manual relationships definition, custom measures, calculated columns, data categorization, and sort by column. There is Relationship View, where user gets a customizable diagram view of all tables and the relationships between them.

Power BI for Office 365 is a cloud based service available via web browser that allows (see [16]):

- Execution of similar report creation process like in Power BI Desktop (import, model, create report).

- Connect to services.

User is able to connect to content packs for a number of services such as Salesforce, Microsoft Dynamics, and Google Analytics. Power BI uses user's credentials to connect to the service, and then creates a Power BI dashboard and a set of Power BI reports that automatically show data and provide visual insights.

- Create Dashboards.

They are personalized and provide user capability to monitor most important data, at a glance. A dashboard combines on-premises and cloud data in a single, consolidated view across the organization.

Sharing the data. In Power BI user can share dashboards, reports, and tiles in several different ways eg. Publish a report to the web, share a dashboard with associates, create a dashboard in a group, then share it with co-workers outside the group.

- Q\&A in Power BI.

Capability of processing natural language user's question and receive answers in the form of charts and graphs.

- Quick Insights.

Power BI searches different subsets of dataset while applying a set of algorithms to discover potentially-interesting insights. Power BI scans as much of a dataset as possible in an allotted amount of time. Example algorithms are: Majority, Category outliers, Overall trends in time series, Correlation and many more.

\section{Research on usage of communication and knowledge management tools on enterprises}

Authors have conducted research to verify how IT tools affect communication in Polish companies, which tools are most popular and where those companies identify the most important advantages. The essence of the study was to determine the direction of development of communication tools used by enterprises. The survey was addressed to employees of IT, HR, corporate communications, and was implemented 
using a combined method: online surveys and telephone interviews. The basic tool used in the study was an anonymous survey directed to employees of enterprises of various lines of business. Those companies were selected on the basis of rankings of enterprises published by Polish business magazines, in which the use of communication solutions is necessary for proper functioning.

A group of 100 companies was selected for the survey.

Regarding the size of the companies that took part in the survey, the majority $(60 \%)$ were medium enterprises, employing between 50 and 249 employees and making an annual turnover not exceeding EUR 50 million. Another group was large companies operating in one country. This group accounted for $34 \%$. The survey covered $6 \%$ of the companies referred to as corporations (operating in many countries) -Fig. 5.

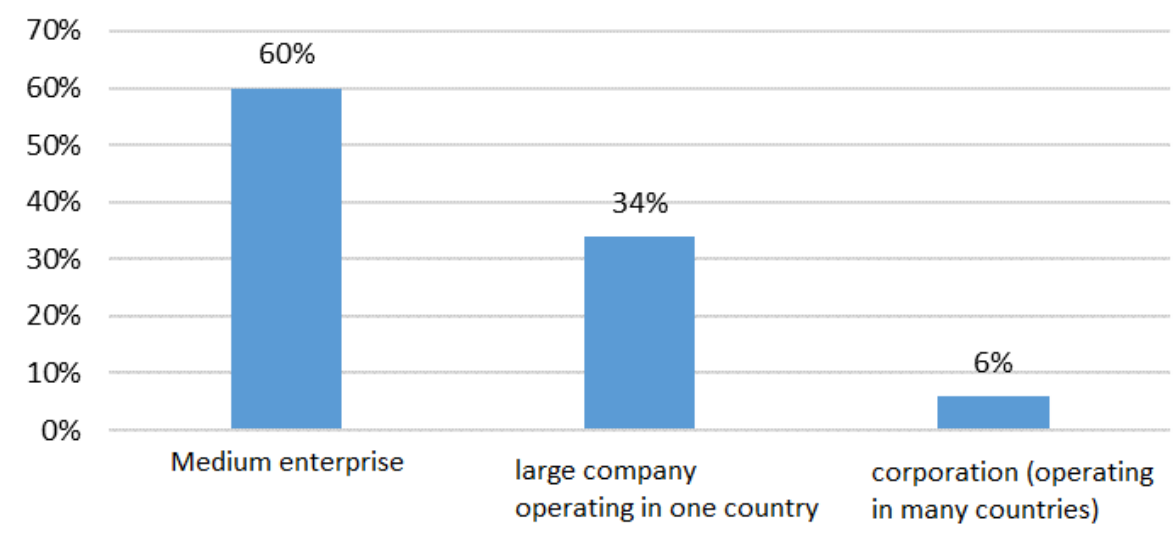

Fig. 5. Number of companies in research divided by the size.

The respondents were asked to evaluate how the use of IT tools in communication affects specific activities (Table 1.). Authors assigned specific weight to each answer, they calculated values and then ranked answers. Respondents pointed out that the use of IT tools for communication speeds up the communication process (rank 1) and enables to perform more effectively the assigned tasks (rank 2). It also influences the creation and consolidation of the positive image of the company. Encouraging employees to communicate was ranked in the lowest position of the indicated actions. It transpires that simply putting IT tools into communication does not make employees to increase contact frequency or they prefer personal contacts. 
Table 1. Impact of IT tools on selected communication process activities

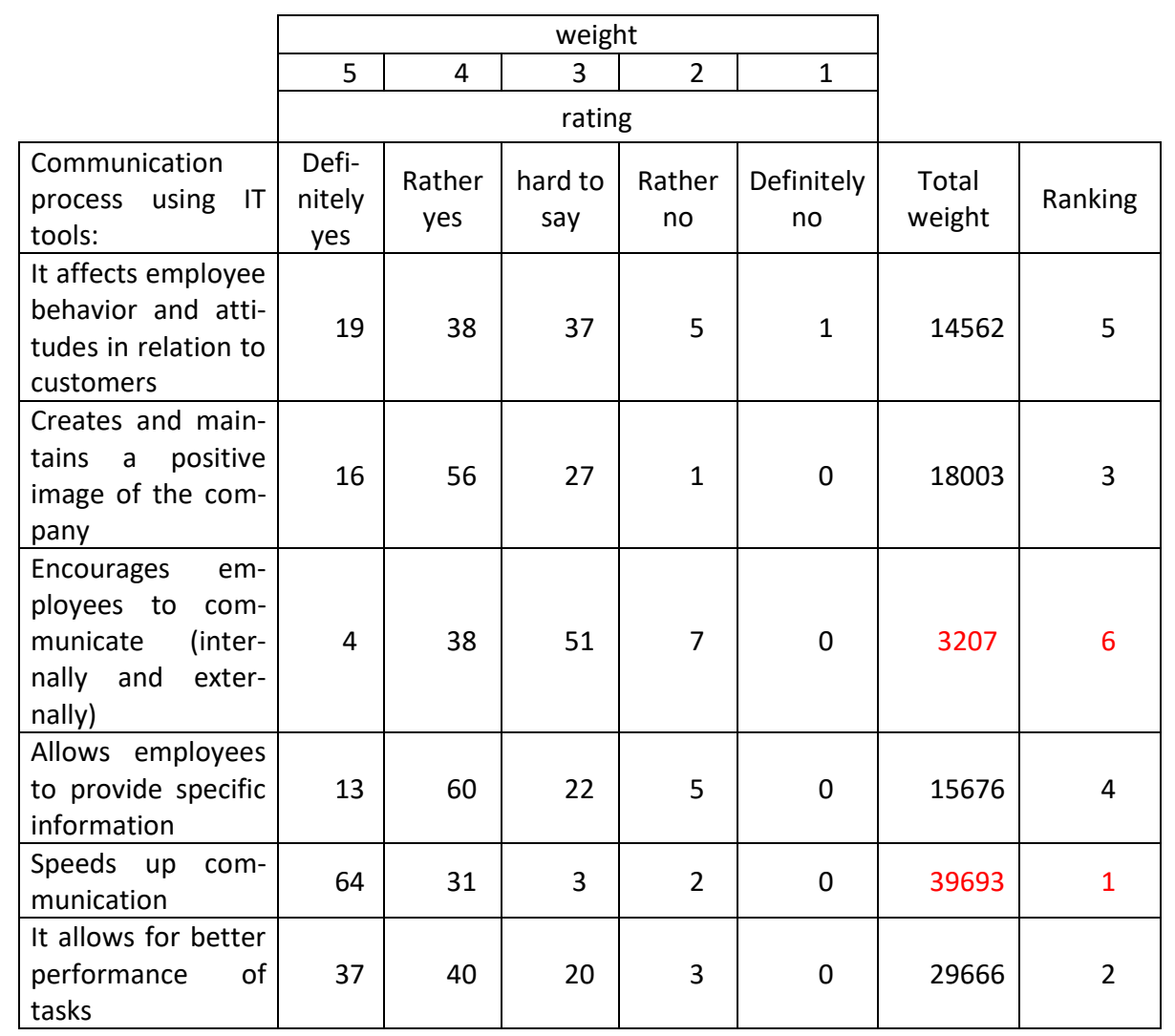

The respondents were asked to evaluate the effectiveness of the indicated communication tools (Table 2.). The highest rating got email (1st place). As many as 94 respondents indicated that this is a very important / important communication tool in enterprises. This is probably due to its popularity, versatility regarding the type of message delivery, time, size and cost of implementation, maintenance, updates. On 2nd place there is intranet / extranet - with 75 important and very important answers. This tool, because of its cost, is not used by all companies, however, in the research it has gained a high position, probably due to its usefulness and development potential. Audio and videoconferencing go places 3 and 4 in the ranking. 5th place take company wikis as a tool playing an important role in the communication process. It is a tool that complements the knowledge of employees and develops as needed, enables teamwork, facilitates the management of large amounts of information, and provides the ability to create knowledge bases and share them with the business environment. 
Table 2. Evaluation of the importance of IT communication tools

\begin{tabular}{|c|c|c|c|c|c|c|c|}
\hline & \multicolumn{5}{|c|}{ Weight } & & \\
\hline & 5 & 4 & 3 & 2 & 1 & & \\
\hline & \multicolumn{5}{|c|}{ Signifficance } & & \\
\hline Tool category & $\begin{array}{c}\text { very } \\
\text { im- } \\
\text { portant }\end{array}$ & $\begin{array}{c}\mathrm{im}- \\
\text { portant }\end{array}$ & $\begin{array}{c}\text { Me- } \\
\text { dium } \\
\text { im- } \\
\text { portant }\end{array}$ & $\begin{array}{c}\text { less } \\
\text { im- } \\
\text { portant }\end{array}$ & $\begin{array}{c}\text { Not } \\
\text { im- } \\
\text { portant }\end{array}$ & $\begin{array}{c}\text { Total } \\
\text { weight }\end{array}$ & $\begin{array}{c}\text { ran } \\
\text { king }\end{array}$ \\
\hline Email & 51 & 43 & 6 & 0 & 0 & 445 & 1 \\
\hline Company wiki & 10 & 23 & 19 & 24 & 24 & 271 & 5 \\
\hline $\begin{array}{l}\text { Intranet (extra- } \\
\text { net) }\end{array}$ & 11 & 64 & 23 & 2 & 0 & 384 & 2 \\
\hline Enterprise blog & 0 & 3 & 8 & 53 & 36 & 178 & 9 \\
\hline Videoconference & 0 & 27 & 39 & 30 & 4 & 289 & 4 \\
\hline Newsletter & 6 & 11 & 40 & 29 & 14 & 266 & 6 \\
\hline Audioconference & 0 & 35 & 45 & 20 & 0 & 315 & 3 \\
\hline Enterprise social & 3 & 20 & 14 & 47 & 16 & 247 & 7 \\
\hline $\begin{array}{l}\text { Instant messag- } \\
\text { ing }\end{array}$ & 3 & 4 & 28 & 37 & 28 & 217 & 8 \\
\hline Others & 0 & 0 & 23 & 17 & 60 & 163 & 10 \\
\hline
\end{tabular}

The results confirm that communication and knowledge management is very important for businesses. IT tools play an important role in improving the efficiency and effectiveness of activities, transferring and gathering content (including knowledge), and therefore business leaders should be aware that well-functioning communication can enable achieving the goals.

As part of the research work, authors have decided to check the level of communication efficiency. Respondents were requested to evaluate each individual element impacting the overall communication efficiency.

Table 3 summarizes the results. As in previous analyses weights have been assigned to specific answers and the summarized values have been calculated. Then the results were divided by the number of respondents and an average value was calculated for each area. Over a half of the respondents (51) assess as good and very good the reliability and completeness of the information received (mean 3.37). A similar number of respondents (48) highly evaluate efficient access to information (average 3.31). The speed of information flow was also considered as high (average 3.26) and the communication atmosphere - average 3.24. IT tools significantly speed up the process of processing access to information. The lowest rated elements were "the amount of information received with reference to information needs" (average 3.22) and the "relevance of communication activities with the needs of employees" (average grade 3.18 ). The ideal situation would be if the amount and type of information 
needed was equal to the amount received. Such situation is of course very difficult to achieve. The latter aspect got the most negative answers (23). It is necessary to pay attention to communication activities in enterprises. The reason of negative ratings may be wrong tools, inability to use them in a correct way or mismatch between expected and executed methods of communication. The reason for the generally low results of the study may be a large number of people indicating the answer "hard to say". The results are shown in Table 3.

Table 3. Evaluation of elements impacting the communication supported by ICT efficiency.

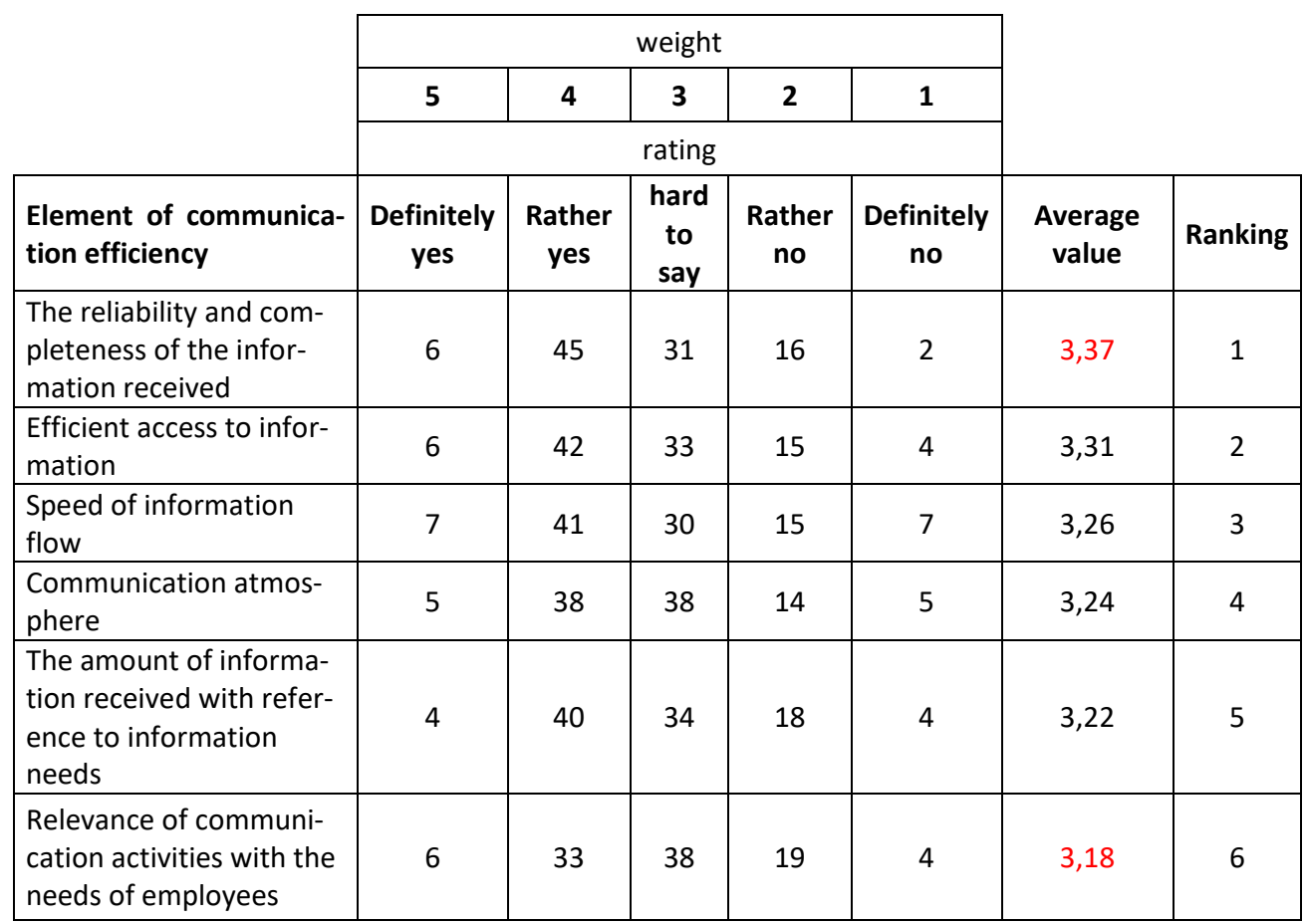

In the next question, the respondents were requested to assess the influence of communication tools on the group work behaviours. Group / team work was understood as cooperation of employees in the execution of the assigned tasks.

As earlier, respondents were asked to rate each category on a 5-point scale. Method of the final rating calculation was the same as in previous case. The results are presented in Table 3.

Respondents assessed that the main reason of using ICT in team and group work is the exchange of experience / knowledge, better results during collaborative work on a task and easier common goal achievement, however, it should be noted that effective performance of tasks in the team is possible due to the appropriate tasks' division between team members. The advantage of team work is not only to facilitate the implementation of tasks through their division, but also to increase productivity, result- 
ing from the fact that the integrated group is more effective in action than individual who is part of a team and communication tools streamline the information and knowledge flow in teams. In subsequent places, we can find the following categories: "to reduce stress and increase creativity", "increase work efficiency", "increase motivation (social facilitation)", "higher sense of responsibility", "obtain faster effects". These activities are related to human traits and have been indicated as significant (average rating of the activities listed from 3.74 to 3.02 ). When creating teams, remember to develop an evaluation system and inform about the applicable rules / criteria all team members before starting their work. The rating of the effects of the group's activities and the contribution of the work of individual people is an extremely difficult task, which is why it must be prepared in detail and verified before the introduction. Collective responsibility should not be used because the team's individual work as well as the entire team and they are assessed as part of the team. During the team's work there may also be conflicts, or situations in which a conflict of interests arose, and its participants try to impose their will on each other. In group work such an event should be solved as soon as possible to prevent their escalation, which will make the whole team's work difficult. Good methods are negotiation and compromise.

Table 4. Influence of communication tools on the group work behaviours

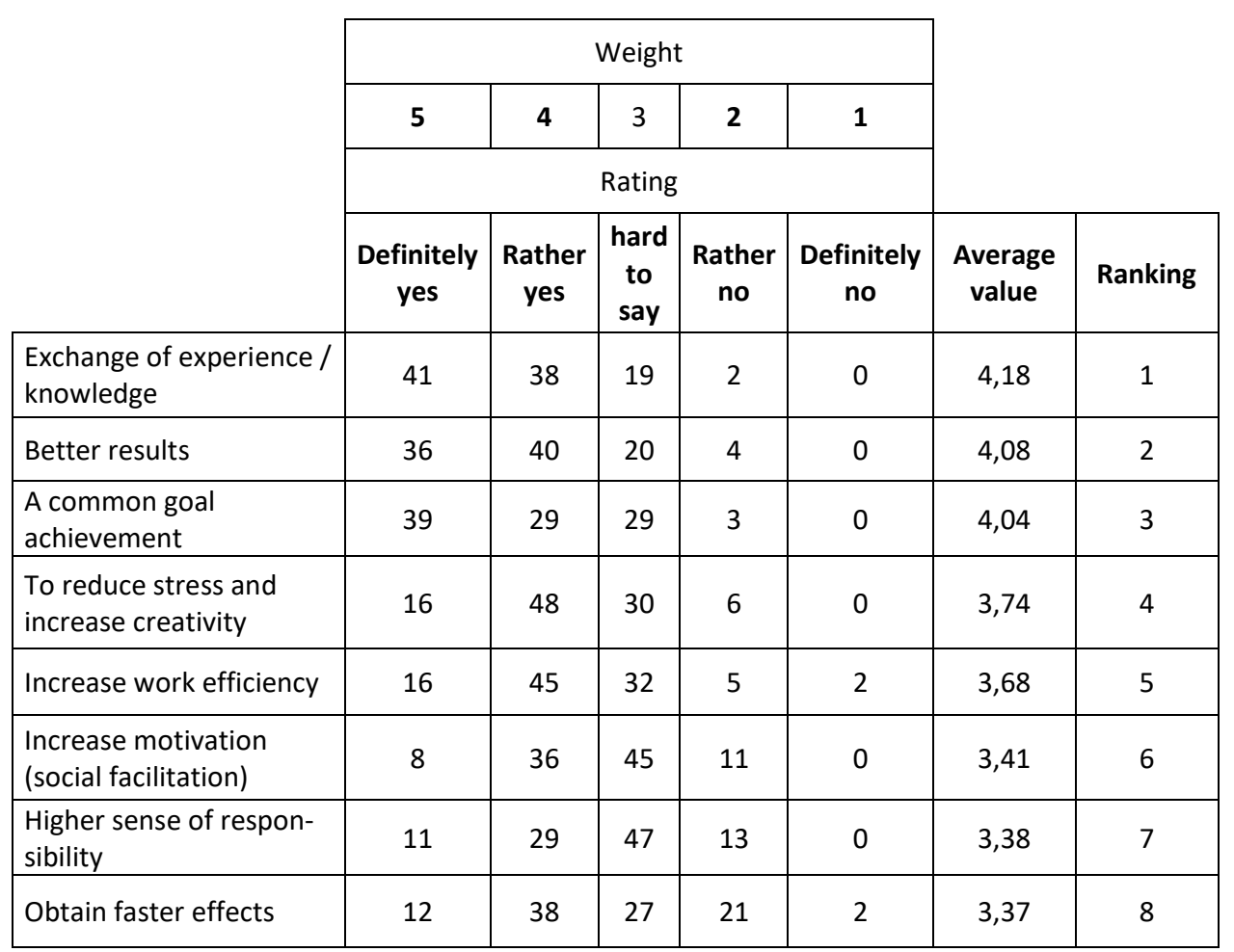




\section{Conclusions}

In current times we have a variety of tools supporting communication and knowledge management. Some of them are easy accessible even for small companies due to the fact that they are available as a service and require only subscription fee to be covered and no huge upfront investments are necessary.

As it transpires from the research, the variety of communication tools does not solve all the communication problems in current enterprises. Employees have a lot of communication tools and channels but at the same time they can suffer from the low level of information relevance or too high amount of information they receive with reference with their actual needs.

Every business should care about high quality communication. Effective communication has the impact on increasing trust in the organization and supporting organizational culture. Well informed employees are more motivated to work better. Without proper communication, the involvement of the staff is low and in extreme cases even the lack of understanding can be experienced. For tasks requiring personal involvement of the employee and his invention, lack of knowledge or understanding of the goal may lead to wrong decisions. At the same time, thanks to their knowledge, employees communicate well with the environment and they convey the right information about the company and its activities.

\section{References}

1. Internetworldstats 2017, World Internet Usage And Population Statistics, http://www.internetworldstats.com/stats.htm,

2. Mała, N., \& Hrabelska, O. (2013). Informacja i komunikacja w zarządzaniu personelem. Nierówności społeczne a wzrost gospodarczy, (36), 317-326.

3. Griffin, R. W., Rusinski, M., \& Rozanska, I. (1999). Podstawy zarzadzania organizacjami; Przekl. M. Rusinski; Konsultacja nauk. B. Glinski; Red. I. Rozanska. Warszawa: Wydaw. Nauk. PWN.

4. Stoner, J. A. F., Freeman, R. E., \& Gilbert Jr, D. R. (2001). Kierowanie, wydanie II. Wydawnictwo PWE, Warszawa.

5. Alavi, M., \& Leidner, D. E. (2001). Knowledge management and knowledge management systems: Conceptual foundations and research issues. MIS quarterly, 107-136.

6. Stankiewicz J. (2006): Komunikowanie się w organizacji, Astrum, Wrocław.

7. Muszyńska, K. (2008). Zarządzanie komunikacją w projekcie w wybranych metodykach zarządzania projektami. Studia i Materiały Polskiego Stowarzyszenia Zarządzania Wiedza, 17, 131-138.

8. O'Hair, D., Friedrich, G. W., Dixon, L. D. (2007), Strategic Communication in Business and the Professions. Allyn \& Bacon.

9. Czekaj, J. (2000). Metody zarządzania informacją w przedsiębiorstwie. Zeszyty Naukowe/Akademia Ekonomiczna w Krakowie. Seria Specjalna, Monografie, (143).

10. Hildenbrand, T., Rothlauf, F., Geisser, M., Heinzl, A., \& Kude, T. (2008, March). Approaches to collaborative software development. In 2008 International Conference on Complex, Intelligent and Software Intensive Systems (pp. 523-528). IEEE. 
11. Techtarget (2015), Issue tracking system (ITS) definition. http://searchcrm.techtarget.com/definition/issue-tracking-system

12. Schmidt, M. T. (1998). Building workflow business objects. In Business Object Design and Implementation II (pp. 64-76). Springer, London.

13. Demeyer, R., Van Assche, M., Langevine, L., \& Vanhoof, W. (2010, July). Declarative workflows to efficiently manage flexible and advanced business processes. In Proceedings of the 12th international ACM SIGPLAN symposium on Principles and practice of declarative programming (pp. 209-218). ACM.

14. Webb C. (2014), Power Query for Power BI and Excel. Apress.

15. Owoc, M., \& Pondel, M. (2016, July). Selection of Free Software Useful in Business Intelligence. Teaching Methodology Perspective. In IFIP International Workshop on Artificial Intelligence for Knowledge Management (pp. 93-105). Springer, Cham.

16. Power BI Desktop (2016) https://powerbi.microsoft.com/en-us/documentation 